\title{
Model Studies for Conceptual Design of Low Flow Weir across Mahaweli Ganga
}

\author{
N.K.M. Nanseer and W.K. Illangasinghe
}

\begin{abstract}
Water extraction at Meewathura Intake has become difficult or impossible without the assistance of submersible pumps during the dry seasons since the river water level drops below the bottom level of the lowest opening of the Intake. A new intake is also planned to be located on the left bank around $300 \mathrm{~m}$ downstream of Meewathura Intake to extract an additional 32,000 m3/day to expand Kandy South Water Supply Scheme. In order to ensure a total of $41,000 \mathrm{~m}^{3} /$ day from a new intake and from the existing intake, it is envisaged that a weir across the Mahaweli is required to raise the river water level during the dry weather and to extract silt free water. The analysis also shows that weir construction is a better proposal compared to other methods available.
\end{abstract}

Construction of such weir across Mahaweli Ganga would cause flood level rise in the upstream and change the river bed and river bank geometry in the area surrounding the weir, particularly downstream of weir. To investigate these effects both Mathematical (MIKE 11) and Physical model studies were conducted. Mathematical Model was used to optimize weir dimension and to predict water level rise due to weir construction. Physical Model was used to optimize weir and intake layout, to investigate river bed scouring and bank erosion pattern, and to determine erosion protection measures. The study concludes that modeling techniques could be applied very effectively for such and similar studies.

Key Words: Low Flow Weir, Mathematical Model, Physical Model, Flood Level Rise, Layout optimization, Sediment Transport.

\section{Introduction}

The water intake and treatment plant located at Meewathura, Peradeniya is used to extract water from Mahaweli Ganga and supply to the Peradeniya University after treatment. Water extraction at Meewathura Intake has become difficult or impossible without the assistance of submersible pumps during the dry seasons since the river water level drops below the bottom level of the lowest opening of the Intake. It has been identified that construction of a weir across the river is a feasible solution to raise the water level. This work will be incol porated into the augmentation program of the Kandy Water Supply Scheme which envisages the construction of a new intake and a treatment plant at Meewathura, and expansion of the existing distribution system.

The Augmentation Plan for the Kandy South Water Supply Scheme envisages the construction of a new Treatment Plant at Meewatura close to the existing University treatment plant, and a new intake for extraction of raw water from the Mahaweli. The existing intake for the University treatment plant is about $300 \mathrm{~m}$ upstream of the treatment plant.
This is a well-type intake on the left bank of Mahaweli River with openings at different levels and is of capacity $9,000 \mathrm{~m}^{3} /$ day. Extraction from this intake at present is difficult during low discharges of the river, as the intake openings are above the river water level. This phenomenon has been more pronounced after the construction of the Kotmale Reservoir due to lowering of the riverbed by excessive sand mining or increased erosion even though the average dry weather flow has increased.

The new intake (refer Figure 1 for location) is to be located on the left bank to extract an additional $32,000 \mathrm{~m}^{3} /$ day. In order to ensure a total of $41,000 \mathrm{~m}^{3} /$ day from a new intake and from the existing intake, it is envisaged that a weir across the Mahaweli is required to raise the river water level during the dry weather. Water availability is not a problem as the dry weather flow in Mahaweli is much higher than the

Eng. N K M Nanseer, BSc. Eng. (Hons) in 1999 at University of Moratuwa, MSc (IHE) in 2003 in the Nethrlands, MIE(Sri Lanka),

C.Eng, Currently working as Water Resources Specialist at Lanka Hydraulic Institute Ltd.

Eng. W.K.Illangasinghe, BSc. Eng.(Hons) at University of Peradeniya,

M.Eng (Japan), MIE(Sri Lanka), C.Eng., Currently holding position of

Project Director for Kandy South Water Supply Project, NWSDB. 
requirement of both intakes, which is less than $0.5 \mathrm{~m}^{3} / \mathrm{s}$.

Extraction of silt free water is also essential since siltation is a common problem in many intakes located in this region. Sarasavia Uyana Intake located in the downstream at Meewathura intake is already facing lot of difficulties due to siltation and sheet pile arrangement similar to weir is used at Getembe Intake to extract silt free water.

Few other options available for extraction of $41,000 \mathrm{~m}^{3} / \mathrm{d}$ during dry seasons are:

1. Extraction from upstream point

Water can be extracted at an upstream location where water level is high enough to extract silt free water and pumped from an Intake on bank to existing and proposed Treatment plant. This option would require a pipeline of about $7 \mathrm{~km}$ and possibly a low weir. This has not been considered, due to higher capital cost, problems associated with land acquisition for pipeline, security and maintenance of pipeline during operations, availability of land for new facilities at present location.

2. Pumping water using submersible pumps Submersible pumps could be used to extract water during low flow periods. It involves additional electricity cost for existing intake. In case of proposed intake which is to be located at the edge of the bank will need to be lowered below the low water level and an approach canal to will need be excavated in

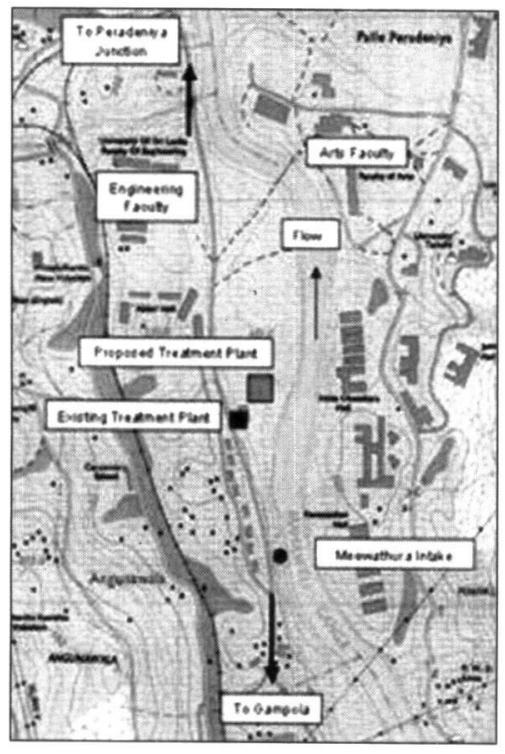

Figure 1: Location Map the river to divert the water into the intake during low flow period. This canal will be silted and desilting will be necessary during operation. In addition, provision has to be made to ensure that silt is water not entering to the intake during high flows. This option involves high operating costs for pumps and difficulties in maintaining silt free water entering into intake.

3. Release of additional flow from Kotmale Reservoir

Additional discharge required to raise the water level to facilitate water extraction during low flow can be released from Kotamle Reservoir. Due to broad width of river the discharge required for this purpose is around $75 \mathrm{~m}^{3} / \mathrm{s}$. This option is not considered as there is no guarantee that such amount of water can be released from Kotmale Reservoir during dry season when water level in the reservoir also could be low in such periods.

Among these options construction of weir across Mahaweli Ganga was selected as the best option since it ensures extraction of silt free water and is less costly when considering the construction, maintenance and operating costs. In addition, it does not disturb the on going operating system of University Intake.

\section{Methodology}

\subsection{Hydrological Analysis}

For the purpose of Hydrological Analysis River Flow at Preadeniya, Water Level at Getambe, Inflow at Kotmale, and Inflow at Polagolla were collected from various organizations and were subjected to data screening using both statistical and conventional methods. The corrected data were used to determine flow characteristics and Flood flows at Peradeniya,

\subsubsection{Flow Characteristics at Peradeniya}

The availability of daily average flow during a year was identified by plotting Flow Duration Curve using the flow data recorded at Peradeniya Gauging Station (Figure 2). From the flow diagram it was interpreted that only $10 \%$ of time in a year river flow falls below $20 \mathrm{~m}^{3} / \mathrm{s}$ while around $90 \%$ of time in a year river flow falls below $155 \mathrm{~m}^{3} / \mathrm{s}$. In another words only $10 \%$ 
of a time in a year the river flow could exceed $155 \mathrm{~m}^{3} / \mathrm{s}$ while around $90 \%$ of time in a year the river flow could exceed $20 \mathrm{~m}^{3} / \mathrm{s}$.

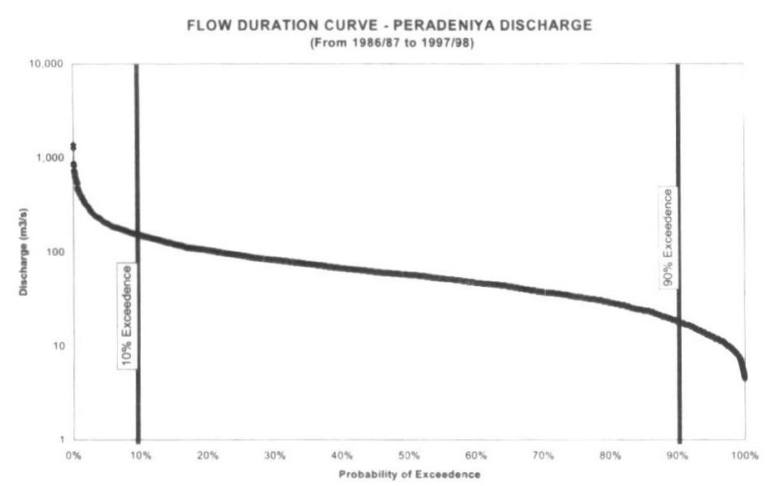

Figure 2: Flow Duration Curve at Peradeniya

\subsubsection{Extreme Value Analysis}

Annual daily maximum values were extracted from the records of daily average flows (after the correction) at Peradeniya collected from Irrigation Department for the period of 25 years. These values were then subjected to different distribution patterns in order to find the best distribution that represents the recurrence interval of flood events more accurately. From the plots of the distributions it was found that Log Normal Distribution fits the data better than other two distribution patterns. Figure 3 shows the plot of distribution and Table 1 shows prediction of flood events respectively.

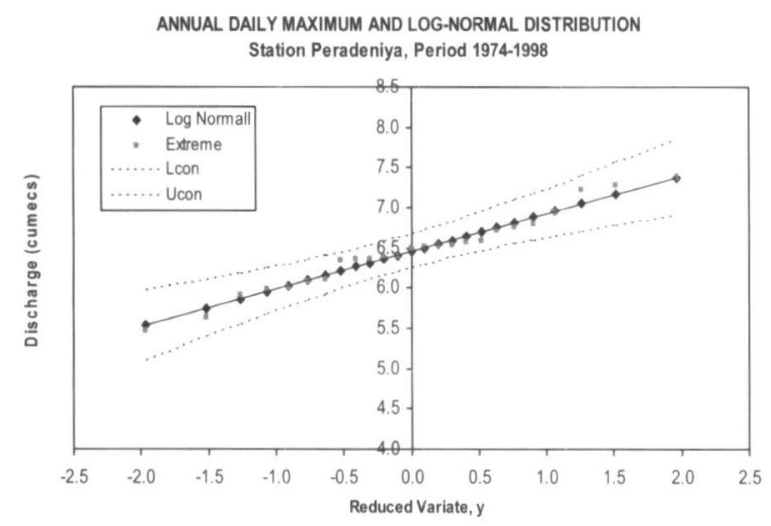

Figure 3: Log-Normal Distribution for Annual Flow at Peradeniya

Table 1: Flood Peaks using Log-Normal Distribution

\begin{tabular}{|l|c|c|c|c|c|c|}
\hline $\begin{array}{l}\text { Return Period } \\
(\mathrm{yr})\end{array}$ & 2 & 5 & 10 & 25 & 50 & 100 \\
\hline $\begin{array}{l}\text { Return Period } \\
(\mathrm{yr})\end{array}$ & 2 & 5 & 10 & 25 & 50 & 100 \\
\hline
\end{tabular}

\subsection{Hydrodynamic Modeling}

Hydrodynamic modeling were carried out using MIKE 11 model software to optimize the location and dimension of the weir, to study the impact of the weir on flood level, to provide the boundary conditions and other data to calibrate the physical model, and to provide pertinent hydraulic characteristics for the sediment transport studies.

\subsubsection{Hydrodynamic Modeling Approach}

The reach of Mahaweli Ganga starting from Nilamba Oya confluence point to Getambe was schematized using river cross sections and the structures that cross the river and constrain to river flow (Peradeniya Road and Railway Bridges for example). The total reach of river schematized was around $11.5 \mathrm{~km}$ (Figure 4).

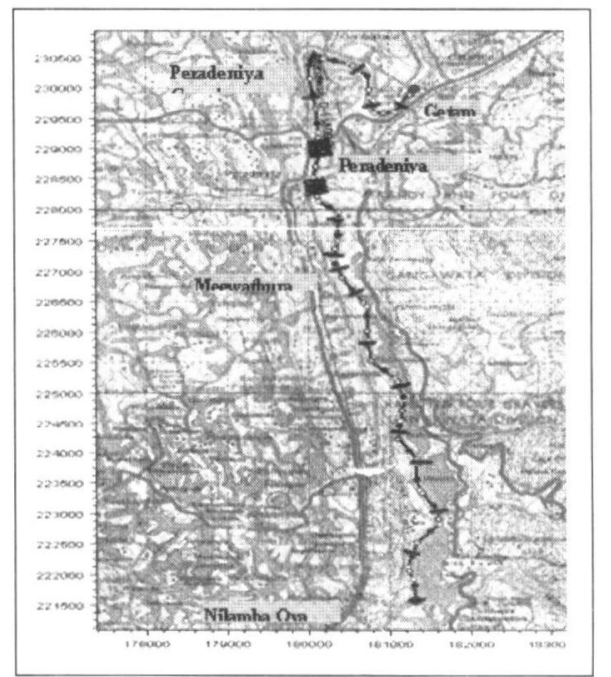

Figure 4: Mahaweli Ganga Network in MIKE 11 (Nilamba Oya to Getambe)

The upstream boundary of River Network was defined as discharge boundary at Nilamba Oya confluence point while the downstream of it was defined as water level boundary at Getambe Intake. For discharge boundary the hourly flow recorded at Peradeniya station for the period starting from January 2005 to March 2005 was used after modifying it to use at Nilamba Oya confluence point.

The model was calibrated using the water levels recorded at Meewathura Intake by comparing it with the water levels of the model estimated at the same location. In the model calibration, attention was specially paid on low flow calibration since it is necessary to decide the top level of the weir and to predict the possibility of 
extracting water at Meewathura Intake through its lowest opening during the dry periods.

\subsubsection{Model Applications}

The calibrated model was used to determine the weir crest level that ensures undisturbed water extraction at Meewathura Intake and to predict the water levels for different flood events before and after incorporating a weir at the proposed location. Model results for different applications are described in Section 3.

\subsection{Physical Model Study}

The purpose of the physical model study was to determine the sedimentation and erosion patterns in the river bed, to recommend design changes where necessary and to investigate and optimize the functioning of the water intakes and the flushing facilities. An undistorted physical model covering a distance of $400 \mathrm{~m}$ upstream and $400 \mathrm{~m}$ downstream of the proposed weir was constructed to a scale of 1 : 40 to investigate the above.

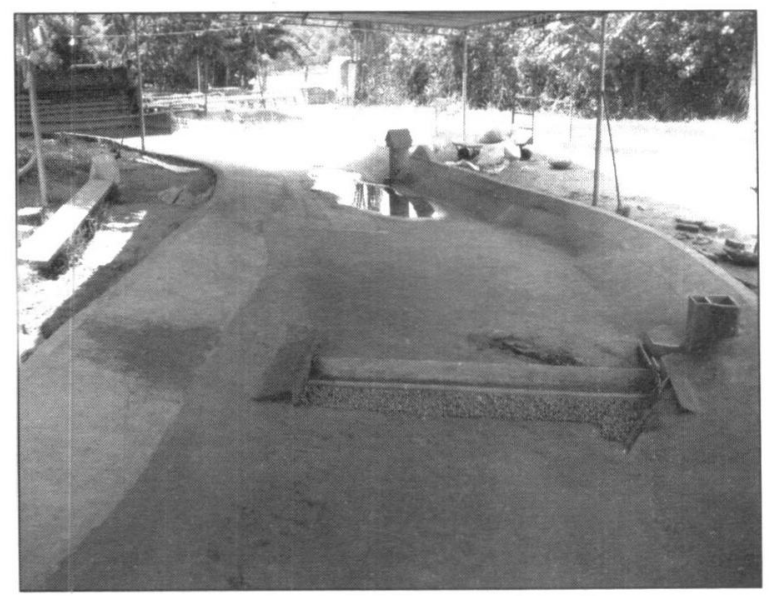

Figure 5: A view on physical model from downstream

\subsubsection{Physical Modeling Approach}

The boundary conditions required for the physical model were obtained from the mathematical model (MIKE11) as water surface elevations downstream of the proposed weir for $90 \%$ of time available flow, $10 \%$ of time available flow in a year and two year return period of flow $\left(20,155\right.$ and $635 \mathrm{~m}^{3} / \mathrm{s}$ respectively).

The model was calibrated for the existing conditions since it was necessary to maintain a high accuracy in order to reduce the scaling effects. The calibration was done by comparing observed water levels and velocities in the physical model with that of the mathematical model.

\subsubsection{Model Applications}

Fixed bed model was used to test the hydraulic aspects of the conceptual layout of the proposed weir and to suggest improvements based on velocity measurements and flow pattern investigations whereas a movable bed model was used to investigate siltation and scour patterns that results from construction of weir at proposed location. Physical model study results are presented in Section 3.

\subsection{Sediment Transport}

The objective of the Morphological study was to obtain the estimates of sediment transport rate in the river reach of Mahaweli Ganga from Nilamba Oya confluence point to Getambe and to predict the upstream bed level change with time due to construction of weir at Meewathura. From Field measurements and investigations it was noted that the bed slope in the downstream part of Mahaweli Ganga (from Nilamba Oya confluence point to Getambe) is mild and the bed level in this river reach has eroded around $0.5-1.0 \mathrm{~m}$ in last 25 years. The river bed of large pebbles or a rocky river bed is visible in many locations at this reach.

\subsubsection{Sediment Transport Rate}

\section{Bed Load Transport Rate}

Based on sand samples collected from the field $D_{50}=5.1 \mathrm{~mm}$ was selected as a mean diameter of bed material for bed load transport computation. The standard soil classification categorizes $D_{50}=5.1 \mathrm{~mm}$ as Gravel and Parker (1979) had found a relation for the gravel transport, which takes the form;

$q_{b}=11.2 \sqrt{\operatorname{Rg} D_{50}} D_{50}\left(\tau^{*}\right)^{1.5}\left[1-\frac{\tau_{c}^{*}}{\tau^{*}}\right]^{4.5}$

where;

$$
\begin{aligned}
\mathrm{q}_{\mathrm{b}}= & \text { Bed load transport }\left(\mathrm{m}^{3} / \mathrm{m} / \mathrm{s}\right) \\
\mathrm{g}= & \text { Gravity acceleration }\left(\mathrm{m}^{2} / \mathrm{s}\right) \tau^{*}=\text { Shields } \\
& \text { number }=\mathrm{H}^{*} \mathrm{~S} /\left(\mathrm{R}^{*} \mathrm{D} 50\right) \\
\tau_{\mathrm{c}}^{*}= & \text { Critical shields number } \\
\mathrm{R}= & \left(\rho_{\mathrm{s}}-\rho_{\mathrm{w}}\right) / \rho_{\mathrm{w}} ;
\end{aligned}
$$


where;

$\mathrm{H}=$ Water Height (m), S-Water Slope,

$D_{50}=$ Material Diameter $(\mathrm{m})$

$\rho_{s}$ - Density of bed material and

$\rho_{w}$ - Density of water

This formula was used to compute the average monthly and annual bed load transport rate using the daily average discharge time series at Peradeniya Gauging Station.

\section{Wash Load Transport Rate}

Information on suspended sediment transport in the project area is given in the report 'Sediment Transport in the Mahaweli Ganga' (Reference 12). In that report a relationship between the suspended sediment transport and water discharge at Peradeniya is derived based on the measurements carried out between 1971 and 1975. The relation given was;

$Q_{s}=1.19 * 10^{-3 *} Q_{w}^{1.88}$

where;

$\mathrm{Qs}=$ Suspended Sediment Rate $(\mathrm{kg} / \mathrm{s})$ and $Q_{w}=$ Water Discharge $\left(\mathrm{m}^{3} / \mathrm{s}\right)$

The above relationship was used to estimate the suspended sediment transport rate at Peradeniya.

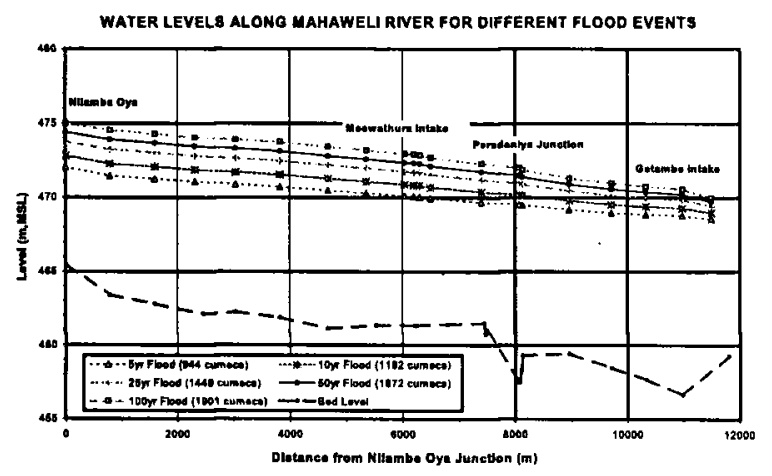

Figure 6: Water Level Profile for Different Floods

\section{Results and Discussions}

\subsection{Hydrodynamic Modeling}

\subsubsection{Flood Level Estimation}

The calibrated MIKE 11 HD module was fed with different flood events and run to predict water level profile along the Mahaweli Ganga (from Nilamba Oya confluence to Getambe). Figure 6 shows the water level profile predicted for different flood events.

\subsubsection{Weir with different top levels}

The influence of weir crest level was checked by considering range of levels starting from +464.0 $\mathrm{m}$ MSL to $+465.0 \mathrm{~m}$ MSL for the low flow of 5 $\mathrm{m}^{3} / \mathrm{s}$. Results (Table 2) indicate that when the weir crest level is kept at $+464.5 \mathrm{~m}$ MSL the water level at Meewathura Intake is around $+464.727 \mathrm{~m}$ MSL, which is about $1.5 \mathrm{~m}$ above from the bottom level of lowest opening of Meewathura Intake. Water level at $+464.727 \mathrm{~m}$ MSL at Meewathura Intake is sufficient to extract the $9,000 \mathrm{~m}^{3} / \mathrm{d}$ from it. Hence it is recommended to adopt the crest level of the weir at $464.5 \mathrm{~m}$ MSL.

Table 2: Water Level for Different Weir Crest Level

\begin{tabular}{|c|c|}
\hline $\begin{array}{c}\text { Weir Top Level } \\
\text { (m MSL) }\end{array}$ & $\begin{array}{c}\text { Water Level at } \\
\text { Meewathura Intake }\end{array}$ \\
\hline 464.0 & 464.220 \\
464.5 & 464.727 \\
465.0 & 465.233 \\
\hline
\end{tabular}

\subsubsection{Flood Level Rise due to Weir}

A weir that has width equal to the width of the river $(\sim 75 \mathrm{~m})$ was considered downstream of the Meewathura Intake (about $250 \mathrm{~m}$ downstream). The top level of the weir was kept at $+464.5 \mathrm{~m}$ MSL and for the inflow and outflow losses at the weir entrance, the default head loss factors defined in MIKE 11 Hydrodynamic model was accepted initially and later altered based on the physical model results. The water level rises at different locations due to construction of weir for the different flood events are presented in Table 3.

Table 3 shows that the water level rise upstream of weir reduces for higher return period floods and water level rise reduces further upstream of the weir. The effect of the weir is not felt at Nilamba Oya confluence point which is about 6 $\mathrm{km}$ from the weir. The reduction in flood level rise upstream of weir for higher return period floods is due to more submergence of weir for higher floods. The highest water level rise estimated upstream of weir for 2 year return period of flood is only $3 \mathrm{~cm}$ and it is lower for higher floods. Hence it is concluded that the weir at crest level of $464.5 \mathrm{~m}$ MSL has no adverse impact on the upstream flood levels. 
Table 3: Water Level Rise due to Weir - Flood Events

\begin{tabular}{|c|c|c|c|c|c|c|}
\hline $\begin{array}{c}\text { Distance } \\
\text { From Weir }(\mathrm{m})\end{array}$ & 55 & 220 & 900 & 2,429 & 3,941 & 6,255 \\
\hline Flood Event & \multicolumn{6}{|c|}{ Water Level Rise due to Weir (m) } \\
\hline $\begin{array}{l}2 \mathrm{yr} \\
\left(635 \mathrm{~m}^{3} / \mathrm{s}\right)\end{array}$ & 0.03 & 0.03 & 0.03 & 0.03 & 0.02 & 0.01 \\
\hline $\begin{array}{l}5 y r \\
\left(994 \mathrm{~m}^{3} / \mathrm{s}\right)\end{array}$ & 0.02 & 0.02 & 0.02 & 0.02 & 0.01 & 0.01 \\
\hline $\begin{array}{l}10 \mathrm{yr} \\
\left(1162 \mathrm{~m}^{3} / \mathrm{s}\right)\end{array}$ & 0.02 & 0.02 & 0.02 & 0.01 & 0.01 & 0.01 \\
\hline $\begin{array}{l}25 \mathrm{yr} \\
\left(1449 \mathrm{~m}^{3} / \mathrm{s}\right)\end{array}$ & 0.02 & 0.02 & 0.02 & 0.01 & 0.01 & 0.01 \\
\hline $\begin{array}{l}50 \mathrm{yr} \\
\left(1,672 \mathrm{~m}^{3} / \mathrm{s}\right)\end{array}$ & 0.02 & 0.02 & 0.02 & 0.01 & 0.01 & 0.01 \\
\hline $\begin{array}{l}100 \mathrm{yr} \\
\left(1,901 \mathrm{~m}^{3} / \mathrm{s}\right)\end{array}$ & 0.02 & 0.02 & 0.01 & 0.01 & 0.01 & 0.01 \\
\hline
\end{tabular}

\subsection{Physical Modeling}

\subsubsection{Fixed Bed Tests}

In the model layout, weir with its appurtenant components such as intake channel, stilling basin and bank protection walls were placed and tested for river flows of $20 \mathrm{~m}^{3} / \mathrm{s}, 155 \mathrm{~m}^{3} / \mathrm{s}$ and $635 \mathrm{~m}^{3} / \mathrm{s}$. Followings were the observations.

- The selected location of the weir, which is 272 $m$ downstream of the existing Meewathura Intake, is suitable and it does not change the river flow pattern significantly.

In general, the effect of the weir is evident during low flow conditions. As the flow increases the structures are submerged.

- The length of weir and crest level are satisfactory. The maximum water level rise observed in the physical model was $2 \mathrm{~cm}$ for 2-year flood. The water level for the low flow $\left(20 \mathrm{~m}^{3} / \mathrm{s}\right)$ can be raised to $464.99 \mathrm{~m} \mathrm{MSL}$ at the existing intake. The water level at 464.99 $\mathrm{m}$ MSL at Meewathura Intake is sufficient to extract $9,000 \mathrm{~m}^{3} / \mathrm{d}$.

- No eddies at the entrance of intake channel due to natural and artificial protection.

- Either side of the river bank had to be protected, and shaped to have smooth flow at the weir.

Required modifications were made to the layout of the weir and intake channel to improve hydraulic performance.

\subsubsection{Mobile Bed Tests}

For the mobile bed tests, the river reach $160 \mathrm{~m}$ upstream and $160 \mathrm{~m}$ downstream from the weir axis was selected and filled with fine sand to represent the river bed material. The selected river reach was then formed to the existing bed pattern. During the tests sand was continuously fed at the upstream so as to ensure a constant supply and the transported sand was collected at downstream end to be reused.

Following modifications were done based on observations during mobile bed tests.

\section{- Stilling Basin}

Optimized parameters are as follows.

(a) The level of stilling basin (top) at 4.61 .0 $m$ MSL.

(b) The length of stilling basin is $4 \mathrm{~m}$.

(c) The downstream lip level at $461.8 \mathrm{~m}$ MSL.

(d) The length of bed protection downstream of the stilling basin is $5 \mathrm{~m}$.

- Sediment Movement at the Entrance of Intake Channel

Entry of fine sand or silt into the intake channel during higher discharges can be prevented by closing the intake channel gate since it would reduces flow velocity in the channel and thus any sediment entering the channel would immediately settle on the channel floor, which is $0.5 \mathrm{~m}$ below intake level. In addition, the alignment of the intake wall was modified by extending the left bank wall to prevent sand entering the intake channel.

\section{- Sediment Entry into the Intake}

The tendency of sediment depositing at water inlet chamber during flood discharges can be overcome by covering water inlet chamber.

\section{- Sediment Flushing from Intake Channel}

Sediment deposited in the intake channel can be flushed out by keeping the flushing gate open for about $35 \mathrm{~min}$ in the prototype. The flushing is most effective when the tail water is low during low flow conditions.

\section{- Bank and Bed Erosion}

Significant erosion was observed downstream of the of intake channel during 
the flushing operation. Erosion was also noted along the left and right banks around and downstream of the weir during high flows. Extent of bank and bed protection and armour size $\left(\mathrm{d}_{50}=\sim 30 \mathrm{~cm}\right)$ were changed to optimize the protection works.

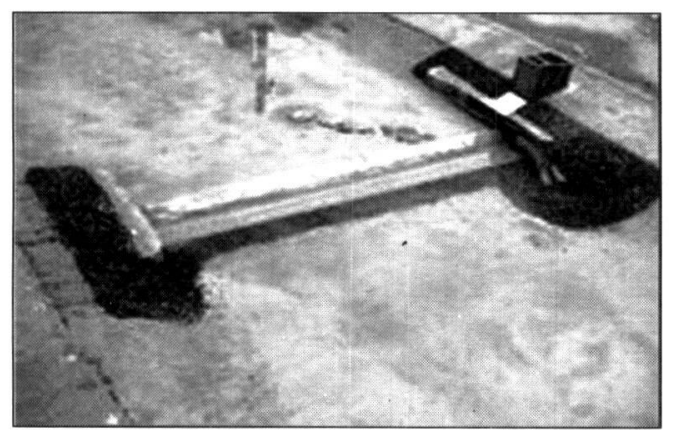

Figure 7: Final Layout of Weir and Intake

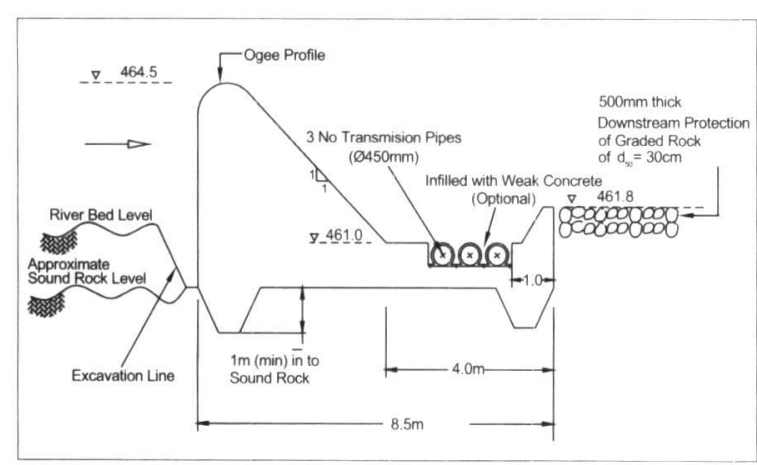

Figure 8: Weir - Sectional View

\subsection{Sediment Transport}

\subsubsection{Sediment Transport Rate}

This formula was used to compute the average monthly and annual bed load transport rate using the daily average discharge time series at Peradeniya Gauging Station. Table 4 summarizes the results.
From Tables 4 it was estimated that the annual total sediment transport is around $282,140 \mathrm{~m}^{3}$ for the catchment including Kotmale Reservoir (Area $\left.=1,141 \mathrm{~km}^{2}\right)$. Accordingly, the sediment yield at Peradeniya is around $247 \mathrm{~m}^{3} /$ year per square kilometers of catchment including Kotmale Reservoir. It should be noted that in phase 1 of the report 'National Sand Study for Sri Lanka (1992)' prepared by Delft Hydraulic where it is stated that the value of $330 \mathrm{~m}^{3} / \mathrm{km}^{2}$ / year had been recommended by UNDP/FAO (1969) and Nedeco (1979) for reservoirs on the main branches of the Mahaweli Ganga. Therefore, one can expect lower sediment yield down stream of reservoir once the reservoir is placed since it will reduce sediment transport considerably.

\subsubsection{Sediment Deposition}

The sediment deposition behind the weir would reduce the reservoir or pond capacity with time. This information is particularly required to predict possible desilting periods and the effects on the intake structures. The desilting periods were estimated based on Brune (1953) formula (Table 5).

\section{Conclusion}

The conceptual designs of weir across Mahaweli Ganga and intake proposed at Meewathura were developed based on the results and observations of the Field Investigations and the Mathematical and Physical modeling studies. The proposed layout of weir and intake ensures silt free water extraction, negligible flood level rise, proper river bed and river bank protection while keeping overall cost low.

Table 4: Transport Rate (1997 to 1998)

\begin{tabular}{|c|c|c|c|c|c|c|c|c|c|c|c|c|c|}
\hline Month & Oct & Nov & Dec & Jan & Feb & Mar & Apr & May & Jun & Jul & Aug & Sep & Total \\
\hline $\begin{array}{l}\text { Suspended } \\
\text { Load, } \mathrm{m}^{3}\end{array}$ & 17116 & 25372 & 6863 & 3456 & 1531 & 1047 & 1811 & 5866 & 21927 & 29917 & 18720 & 16956 & 151968 \\
\hline Bed Load, $\mathrm{m}^{3}$ & 15842 & 21327 & 6143 & 2965 & 877 & 667 & 1625 & 5606 & 20688 & 22928 & 17026 & 14478 & 130172 \\
\hline
\end{tabular}

Table 5: Silting Period - Normal

\begin{tabular}{|c|c|c|c|c|c|}
\hline $\begin{array}{c}\text { Level At } \\
\text { (m MSL) }\end{array}$ & $\begin{array}{c}\text { Storage }{\left(\mathbf{m}^{3} \text { ) }\right.}_{\text {B }} \\
\text { Behind Weir }\end{array}$ & $\begin{array}{c}\text { Annual River } \\
\text { Inflow (MCM) }\end{array}$ & $\begin{array}{c}\text { (Reservoir Capacity)/ } \\
\text { (Annual River Inflow) }\end{array}$ & $\begin{array}{c}\text { Trap } \\
\text { Efficiency }\end{array}$ & $\begin{array}{c}\text { Time to } \\
\text { Silt Up (yr) }\end{array}$ \\
\hline 462.5 & 93,556 & 2,066 & 0.00005 & $\sim 5 \%$ & 6.5 \\
463.5 & 312,976 & 2,066 & 0.00015 & $\sim 5 \%$ & 22.2 \\
464.5 & 667,112 & 2,066 & 0.00032 & $\sim 5 \%$ & 47.3 \\
\hline
\end{tabular}




\section{References}

1. Acker P, White W.R, Perkins J.A., and Harrison A.J.M., 1978, 'Weirs and Flumes for Flow Measurement'.

2. Breusers H.N.C., 'Rivers and River Hydraulics', A lecture notes $(\mathrm{HH} 067 / 87 / 1)$ at IHE -The Netherlands.

3. Brune, G.M, June 1953, ' Trap Efficiency of Reservoirs', Trans.Am. Geophys. Union, Vol.34, pp 407-418.

4. Dharmasena,G.T. and Premesiri S.M., December 1990, 'Rainfall Intensities Studies for Sri Lanka', Engineering Magazine, IESL.

5. Delft Hydraulics - The Netherlands, April 1992, ‘National Sand Study for Sri Lanka (1992).

6. Acker P, White W.R, Perkins J.A., and Harrison A.J.M., 1978, 'Weirs and Flumes for Flow Measurement'.

7. Breusers H.N.C., 'Rivers and River Hydraulics', A lecture notes (HH067/87/1) at IHE -The Netherlands.

8. Brune, G.M, June 1953,' Trap Efficiency of Reservoirs', Trans.Am. Geophys. Union, Vol.34, pp 407-418.

9. Dharmasena,G.T. and Premesiri S.M., December 1990, 'Rainfall Intensities Studies for Sri Lanka' , Engineering Magazine, IESL.
10. Delft Hydraulics - The Netherlands, April 1992, 'National Sand Study for Sri Lanka - Phase One', Final Report prepared for Ministry of Foreign Affairs, The Netherlands and Central Environment Authority, Sri Lanka.

11. Department of the Army Corps of Engineers, April 1984, 'Engineering Manual for Water Supply and Water Resources', EM 1110-3-161 \& 162.

12. Irrigation Department, February 1984, 'Sediment Transport in the Mahaweli Ganga'.

13. Lahmeyer International, December 2000, 'Project Memorandum PM3 - Hydrology' - Appendix A, prepared for Mahaweli Authority of Sri Lanka.

14. Ray K. Linsley, JR., Max A. Kohler and Joseph L.H. Paulhus, 1988, 'Hydrology for Engineers' SI Metric Edition, pp 309-321.

15. Schwab, G.O., Fangmeier, D.D., Elliot, W.J. and Freveret, R.K., 1993, 'Soil and water conservation engineering', J. Wiley and sons. New York. pp507.

16. United States Department of the Interior Bureau of Reclamation, 1973 (Second Edition), 'Design of Small Dams'.

17. United States Department of the Interior Bureau of Reclamation, 1978 (Fourth Edition), 'Hydraulic Design of Stilling Basin and Energy Dissipaters'. 